\title{
Fitoremedijacija - pregled stanja i perspektiva
}

\author{
N. Milčić, Z. Findrik Blažević i M. Vuković Domanovac
}

Fakultet kemijskog inženjerstva i tehnologije, Sveučilište u Zagrebu

Marulićev trg 19, 10000 Zagreb

\begin{abstract}
Sažetak razumijevanja procesa u cjelini, posebice na genetičkoj i biokemijskoj razini.

Ključne riječi

Fitoremedijacija, onečišćenje tla, teški metali, organske onečišćujuće tvari, ksenobiotici
\end{abstract}

Remedijacija tala onečišćenih kompleksnim mješavinama organskih tvari i teških metala jedan je od najvećih izazova obnavljanja okoliša. Fitoremedijacija je naziv za skup postupaka koji upotrebljavaju biljke, njihove enzime i prisutne mikroorganizme iz zone korijenja za izolaciju, transport, detoksikaciju i mineralizaciju ksenobiotika, čime se smanjuje njihova koncentracija, pokretljivost ili toksični učinci. Fitoekstrakcija, fitostabilizacija, fitovolatizacija, fitorazgradnja i rizorazgradnja imaju velik potencijal za nedestruktivnu remedijaciju tala, što pokazuju brojna istraživanja u laboratorijskom mjerilu. Kako bi fitoremedijacija postala pouzdana tehnologija za širok spektar primjena u većem mjerilu, potrebno je ulagati resurse u nova istraživanja s ciljem boljeg

\section{Uvod}

Kakvoća tala izravno utječe na očuvanje bioraznolikosti, održivost ekosustava, ${ }^{1}$ ljudski razvoj, zdravlje i sigurnost. Unatoč porastu globalne svijesti o onečišćenju okoliša, tla i dalje pate od lošeg upravljanja u mnogim područjima. ${ }^{2,3}$ Osjetljiva su na kratkoročna i dugoročna onečišćenja, ${ }^{1}$ a čak i niske razine onečišćujućih tvari čine potencijalnu opasnost u vidu biomagnifikacije. ${ }^{4}$ Budući da je postanak tla kompleksan proces koji može trajati i milijunima godina, ${ }^{5}$ pri odabiru metode remedijacije, osim ekonomske isplativosti, potrebno je uzeti u obzir i nedestruktivnost, kako bi metoda omogućila očuvanje značajki tla i prirodne mikroflore tijekom i nakon dekontaminacije. ${ }^{1}$ Nedestruktivna remedijacija tla moguća je upotrebom biljnih organizama s visokim potencijalom za unos, akumuliranje, metaboliziranje i stabilizaciju ksenobiotika. ${ }^{6}$ Skup tehnika koje upotrebljavaju biljne organizme u remedijaciji okoliša naziva se fitoremedijacija.

\section{Fitoremedijacija}

Pojam fitoremedijacija (grč. $\varphi v \tau o ́$ - biljka, lat. remedio liječiti, sanirati) odnosi se na skup postupaka koji upotrebljavaju biljke, njihove enzime i okolišne mikroorganizme prisutne u zoni korijenja za izolaciju, transport, detoksikaciju i mineralizaciju ksenobiotika u tlu, čime se smanjuje njihova koncentracija, pokretljivost ili toksični učinci. ${ }^{7,8}$ Fitoremedijacija se primjenjuje za uklanjanje alarmantnih vrsta onečišćujućih tvari i njegovih kompleksnih mješavina. ${ }^{9}$ To su teški metali, radionuklidi i organski ksenobiotici koji većinom dospijevaju u tlo kao rezultat rutinskih antropogenih aktivnosti u poljoprivrednom sektoru, atmos-

*Autor za dopisivanje: Nevena Milčić, mag. ing. oecoing.,

e-pošta: nmilcic@fkit.hr ferskim taloženjem iz zraka i nepravilnim odlaganjem otpada. Fitoremedijacija se u literaturi poglavito navodi kao nova tehnologija čiji začetci sežu u početak 1980-ih godina. ${ }^{10-12}$ Međutim, tehnički koncepti za fitoremedijaciju potječu iz više od 300 godina napredaka u melioraciji tla, agronomiji i očuvanju okoliša. Biljke se stotinama godina upotrebljavaju za sprječavanje erozije tla, obradu otpada i očuvanje kakvoće vode. Prepoznavanje fitoremedijacije kao potencijalnog rješenja za sanaciju tala u posljednjih je 35 godina usmjerilo fokus znanstvene zajednice na istraživanja tih procesa. ${ }^{13,14}$ Postignuti su veliki napretci u razumijevanju mehanizama te spektru mogućnosti primjene fitoremedijacije, što je rezultiralo mnogim implementacijama i titulom inovativne metode. Prema današnjem vidu fitoremedijacije, prednosti nad ostalim postupcima obrade tla su: vrlo velika učinkovitost pri niskim koncentracijama onečišćujućih tvari, mogućnost istodobne obrade velikih površina, ekološka prihvatljivost, ekonomičnost, izvedba in situ, estetska prihvatljivost te prihvaćenost od javnosti. ${ }^{6,8}$ Iznimna ekološka prihvatljivost objašnjava se sposobnošću biljaka u uklanjanju onečišćujućih tvari bez negativnih utjecaja u površinskom sloju tla, čime se štiti njegova produktivnost i plodnost. ${ }^{8}$ Biljne vrste velikog pokrovnog i korijenskog sustava sprječavaju eroziju vjetrom i vodom, čime se smanjuje rizik od širenja onečišćujućih tvari i time smanjuju povezani štetni učinci na zdravlje. ${ }^{15} \mathrm{Ci}$ jena postavljanja i održavanja je daleko najniža u usporedbi s ostalim mogućim postupcima remedijacije tala. ${ }^{8}$ Tako prema M. N. Prasad i sur., ${ }^{16}$ fitoremedijacija je za manje od $5 \%$ povoljnija od alternativnih metoda. Profit primjene fitoremedijacije moguće je postići takozvanim fitorudarenjem (engl. phytomining), odnosno upotrebom biljaka sa sposobnošću fitoakumulacije metala koji imaju tržišnu vrijednost. ${ }^{8,17}$ Višestruku korist fitoremedijacije moguće je postići i upotrebom brzorastućih biljnih vrsta velike biomase za remedijaciju tla te naknadno proizvodnju energije. ${ }^{8,18}$ Estetska prihvatljivost nužna je kada je potrebno pronaći rješenje za urbane i turističke sredine, a zajedno 
s neinvazivnošću postupka doprinosi odobravanju od strane javnosti. Suprotno prednostima, ograničavajući faktori kod odabira fitoremedijacije za određenu namjenu su: ograničenje primjene za onečišćenja na većim dubinama tala od zone korijenja, ograničenje primjene pri visokim koncentracijama onečišćujućih tvari, sporija remedijacija u odnosu na fizikalno-kemijske procese, svojstva i toksičnost produkata biorazgradnje mogu biti nepoznati, rezultati su varijabilni, ponekad je potrebna biostimulacija te postoji rizik od dospijevanja onečišćujućih tvari i njihovih razgradnih produkata u hranidbeni lanac. 1,8,19,20 Primamljivost fitoremedijacije potaknula je znanstvenike za istraživanja usmjerena navedenim nedostatcima.

\section{Mehanizmi fitoremedijacije}

Prema mehanizmu djelovanja na onečišćujuće tvari, tehnike fitoremedijacije dijele se na fitoekstrakciju, fitofiltraciju, fitostabilizaciju, fitovolatizaciju, fitorazgradnju i rizorazgradnju (slika 1). ${ }^{1,21}$ Fitoekstrakcija, poznata još kao fitoakumulacija i fitoapsorpcija, odnosi se na unos onečišćujućih tvari iz tla ili voda korijenskim sustavom, prijenos u vaskularna tkiva te akumulaciju u biljnim izbojcima. Tim putem saniraju se tla onečišćena teškim metalima. Prijenos metala u izbojke, odnosno nadzemnu biomasu za žetvu, ključan je biokemijski proces jer je uklanjanje korijenske biomase općenito slabo izvedivo. ${ }^{8,22}$ Fitofiltracija je uklanjanje onečišćujućih tvari iz vodenog medija, bilo da se radi o površinskim ili otpadnim vodama. Već prema dijelu biljke odgovornom za uklanjanje, fitofiltracija se dijeli na rizofiltraciju (korijen), blastofiltraciju (sadnice) i kaulofiltraciju (izdvojeni biljni izdanci). U fitofiltraciji onečišćujuće tvari se apsorbiraju odnosno adsorbiraju na biljno tkivo i time se njihovo kretanje svodi na minimum. ${ }^{8,22}$ Može se reći da je fitofiltracija u vodenom mediju ekvivalentna fitostabilizaciji u tlu. Fitostabilizacija se odnosi na postavljanje biljnog pokrova na površini onečišćenog tla s ciljem ograničenja kretanja i bioraspoloživosti onečišćujućih tvari akumuliranjem unutar korijenja ili imobilizacijom u rizosferi taloženjem, kompleksiranjem ili redukcijom. Tim postupkom smanjuje se migracija onečišćujućih tvari uslijed erozije vjetrom $\mathrm{i}$ vodom. Fitoremedijacija se primjenjuje kada sanacija onečišćenog područja nije prioritet. Onečišćujuće tvari se zadržavaju in situ kako ne bi migrirale do sanacije. ${ }^{23}$

Fitovolatizacija je unos onečišćujućih tvari, pretvorba u hlapljivi oblik i otpuštanje transpiracijom u atmosferu (slika 1). Voda s otopljenim onečišćujućim tvarima ulazi kroz biljno korijenje te se zajedno izlučuju u obliku vodene pare i plinova kroz otvore na lisnoj epidermi, tzv. puči. Na taj način onečišćujuće tvari se ne uklanjanju, već samo prelaze iz jedne okolišne sastavnice u drugu. Drugim riječima, tvari mijenjaju agregatno stanje te prelaze iz tla u atmosferu odakle je ponovno moguća njihova precipitacija. $8,23,24$ Fitorazgradnja se odnosi na razgradnju odnosno metaboliziranje organskih ksenobiotika i podrazumijeva unos onečišćujućih tvari u biljna tkiva analogno unosu teških metala. Na uspješnost fitorazgradnje ponajprije utječe bioraspoloživost te mehanizam unosa tvari i ne ovisi o rizosferskim mikroorganizmima, nego o biljnim metaboličkim enzimima poput dehalogenaza i oksidaza. Rizorazgradnja

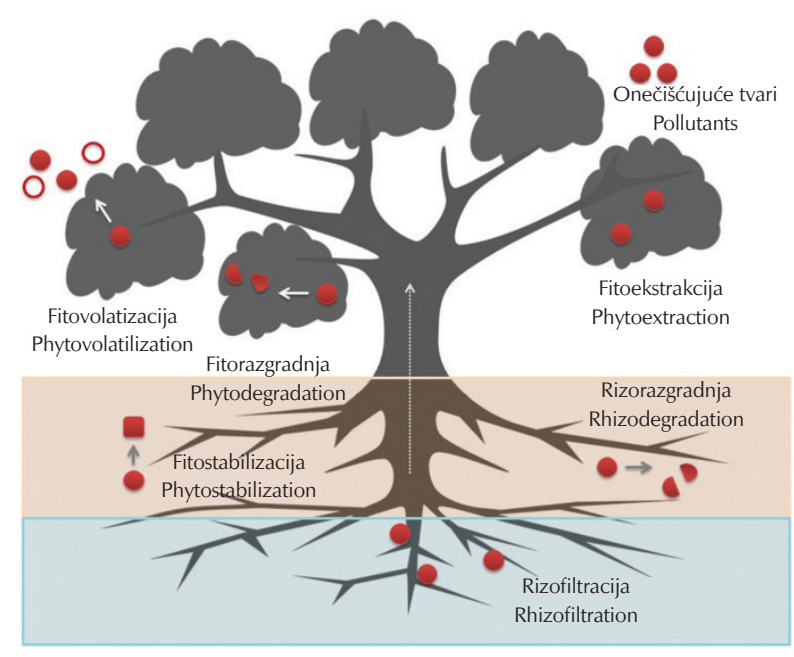

Slika 1 - Mehanizmi fitoremedijacije

Fig. 1 - Mechanisms of phytoremediation

ili fitostimulacija zapravo je fitorazgradnja ex planta, buduću da do razgradnje dolazi zajedničkim djelovanjem izlučenih enzima i mikroorganizama u zoni korijenja. ${ }^{25,26}$ Fitorazgradnja je ograničena na uklanjanje organskih onečišćujućih tvari budući da su teški metali biološki nerazgradljivi. ${ }^{8}$

\section{Fitoremedijacija prema tipu onečišćenja}

Učinkovitost fitoremedijacije najviše ovisi o odabiru biljne vrste za sanaciju određenog područja. Pri odabiru najprikladnije biljne vrste ponajprije je potrebno uzeti u obzir tip onečišćenja te svojstva, pokretljivost i dubinsku raspodjelu onečišćujućih tvari a potom razmotriti ostale faktore poput svojstava tla te okolišnih i klimatskih uvjeta. ${ }^{1}$ Neki primjeri biljnih vrsta uspješnih u fitoremedijaciji prikazani su u Tablici 1.

\subsection{Uklanjanje teških metala}

Teški metali uključuju metale i polumetale čija je gustoća veća od $5 \mathrm{~g} \mathrm{~cm}^{-3}$. Ta skupina uključuje mikronutrijente poput kobalta, bakra, željeza, kroma, molibdena, mangana i cinka te biološki neesencijalne elemente poput kadmija, kroma, olova, žive, nikla, uranija, vanadija i wolframa. lako su manje gustoće, arsen, bor i selenij također se uobičajeno uključuju u tu skupinu. ${ }^{2,19}$ Teški metali najtrajnija su i najsloženija vrsta onečišćujućih tvari kada je u pitanju remedijacija u prirodi. Ne samo da degradiraju kvalitetu atmosfere, vodnih tijela i usjeva hrane već ugrožavaju zdravlje i dobrobit biljaka, životinja i ljudi. Kako neesencijalni, tako su i esencijalni teški metali toksični za žive organizme pri povišenim koncentracijama te postoji velik rizik od biomagnifikacije. Naime, za razliku od većine organskih spojeva, metali nisu podložni metaboličkoj razgradnji, stoga se akumuliraju u tkivima organizama. Time se njihova koncentracija povećava u tkivima članova hranid- 
Tablica 1 - Primjeri biljnih vrsta uspješnih u fitoremedijaciji onečišćujućih tvari

Table 1 - Examples of plant species successful in phytoremediation

\begin{tabular}{|c|c|}
\hline $\begin{array}{l}\text { Biljna vrsta } \\
\text { Plant species }\end{array}$ & $\begin{array}{l}\text { Onečišćujuće tvari } \\
\text { Pollutants }\end{array}$ \\
\hline $\begin{array}{l}\text { Jednogodišnji suncokret } \\
\text { Common Sunflower } \\
\text { (Helianthus annuus) }\end{array}$ & $\begin{array}{c}\mathrm{Co}, \mathrm{Cr}^{27} \\
\mathrm{Zn}^{28} \\
\mathrm{~Pb}, \mathrm{Cd}^{29}\end{array}$ \\
\hline $\begin{array}{l}\text { Slonova trava } \\
\text { Pennisetum } \\
\text { (Pennisetum sp.) }\end{array}$ & $\begin{array}{c}\mathrm{Cu}, \mathrm{Cd}^{28} \\
\text { Klorbenzen (chlorobenzene) })^{30}\end{array}$ \\
\hline $\begin{array}{c}\text { Vodeni zumbul } \\
\text { Water hyacinth } \\
\text { (Eichhornia crassipes) }\end{array}$ & $\begin{array}{c}\mathrm{Fe}, \mathrm{Cu}^{31} \\
\mathrm{Cr}^{32} \\
\mathrm{Zn}, \mathrm{Cd}, \mathrm{Pb}, \mathrm{Ag} \mathrm{Ni}^{33}\end{array}$ \\
\hline $\begin{array}{c}\text { Pravi lan } \\
\text { Flax } \\
\text { (Linum usitatissimum) }\end{array}$ & $\begin{array}{c}\mathrm{Pb}, \mathrm{Zn}^{34} \\
\mathrm{Cd}^{35} \\
\mathrm{Ni}^{36}\end{array}$ \\
\hline $\begin{array}{l}\text { Uljana repica } \\
\text { Canola } \\
\text { (Brassica napus L.) }\end{array}$ & $\begin{array}{c}\mathrm{Pb}, \mathrm{Zn}, \mathrm{Cd}^{37} \\
\mathrm{Cu}^{38}\end{array}$ \\
\hline $\begin{array}{c}\text { Topola } \\
\text { Poplar tree } \\
\text { (Populus spp.) }\end{array}$ & $\begin{array}{c}\mathrm{Cd}, \mathrm{Ni}^{39} \\
\text { nitrati }^{40} \\
\text { TNT, heksogen (RDX) } \\
\mathrm{PAH}^{42} \\
\mathrm{PCB}^{43} \\
\end{array}$ \\
\hline $\begin{array}{c}\text { Vrba } \\
\text { Willow } \\
\text { (Salix spp.) }\end{array}$ & $\begin{array}{l}\mathrm{Cd}, \mathrm{Zn}, \mathrm{Pb}^{44} \\
\mathrm{PAH}^{42}\end{array}$ \\
\hline
\end{tabular}

benog lanca proporcionalno trofičkim razinama, čime su organizmi na vrhu hranidbenog lanca najugroženiji. ${ }^{2,45,46}$ Biljne vrste prirodno imaju visoko specifične i učinkovite mehanizme za unos esencijalnih metala. One proizvode kelatna sredstva te provode oksidacijsko-redukcijske reakcije i promjene $\mathrm{pH}$ vrijednosti koje pomažu biljnom korijenju u otapanju i unosu teško topljivih taloga esencijalnih metala čak i u vrlo niskim količinama. Unos i transport uobičajeno se odvijaju putem protonskih pumpi, proteinskih nosača (integralnih membranskih proteina) ili antiportera (tipa kanalnih proteina) u staničnoj membrani korijena. Međutim, i neesencijalni teški metali mogu se prenositi tim mehanizmima, pogotovo pri niskim koncentracijama esencijalnih metala. ${ }^{22}$ lako su primarno toksični, teški metali nemaju jednak učinak na sve biljne vrste. Pri izlaganju teškim metalima biljne vrste mogu pokazati svojstvo osjetljivosti ili svojstvo rezistentnosti. Svojstvo osjetljivosti uzrokuje oštećenja ili smrt biljaka, budući da metali interferiraju s fiziološkim i biokemijskim procesima poput fotosinteze i respiracije te doprinose propadanju organela i stanica. Svojstvo rezistentnosti omogućuje biljkama da prežive visoke koncentracije metala te stvaraju iduće generacije. Budući da su biljke sesilni organizmi i nemaju mogućnost napustiti onečišćena područja, bile su prisiljene razviti specifične biološke mehanizme za prilagodbu metalnom stresu. Rezistentnost uključuje izbjegavanje unosa teških metala u nadzemna tkiva, pospješeno izbacivanje i povećanu toleranciju na unos. ${ }^{19,47,48}$ Povećana tolerancija na unos posebno je zanimljiva s aspekta fitoremedijacije, specifičnije fitoekstrakcije. Brooks i sur. ${ }^{49}$ prvi put su 1977. godine uveli izraz hiperakumulatori za biljne vrste s velikom sposobnošću ekstrakcije i akumulacije nikla. Hiperakumulatori metala pripadaju međusobno daleko srodnim biljnim porodicama, no dijele sposobnost nakupljanja iznimno velikih količina teških metala u nadzemnim organima. To odgovara 100 do 1000 puta većim koncentracijama u tkivu od onih uobičajenih za biljke, odnosno više od $10 \mathrm{mg} \mathrm{g}^{-1}(1 \%)$ za $\mathrm{Mn} \mathrm{i} \mathrm{Zn,} \mathrm{više} \mathrm{od} 1 \mathrm{mgg}^{-1}(0,1 \%)$ za As, $\mathrm{Co}, \mathrm{Cr}, \mathrm{Cu}, \mathrm{Ni}, \mathrm{Pb}, \mathrm{Sb}$, Se i Tl te više od $0,1 \mathrm{mg} \mathrm{g}^{-1}$ $(0,01 \%)$ za $\mathrm{Cd}$. Osim povećane stope unosa teških metala, obilježja koja razlikuju hiperakumulatore od ostalih biljnih vrsta su brži prijenos onečišćujućih tvari od korijenja do izbojaka i veća sposobnost za detoksikaciju i odjeljivanje teških metala od ostalih dijelova biljke. Oko 45 \% vrsta hiperakumulatora su Angiospermae (kritosjemenjače), a od njih $25 \%$ pripada porodici Brassicaceae (krstašice). Mnoga istraživanja pokazuju da su Brassicaceae posebice uspješne u uklanjanju nikla (rodovi Thlaspi i Alyssum), kadmija i cinka (Thlaspi caerulescens, Thlaspi praecox, Thlaspi goesingense i Arabidopsis halleri). ${ }^{50}$ Budući da hiperakumulatori koncentriraju ciljane metale u razmjerno maloj nadzemnoj biomasi, osnova su za fitorudarenje, proces upotrebe biljaka za ekstrakciju i oporabu teških metala s tržišnom vrijednošću. Ekonomičnost procesa fitorudarenja ovisi o velikom broju čimbenika, poput sadržaja metala u tlu i biljkama, godišnjoj proizvodnji biomase te mogućnošću naknadne proizvodnje energije iz nastale biomase, a najvažniji čimbenik je tržišna cijena metala. Najbolji izbor za fitorudarenje su zlato, talij, kobalt i nikal zahvaljujući visokoj cijeni te visokoj mogućnosti koncentriranja u biomasi hiperakumulatora. ${ }^{17}$ Osim upotrebe hiperakumulatora, u fitoekstrakciji je moguća upotreba brzorastućih biljaka velike biomase. Primjeri su Brassica juncea (smeđa gorušica) i Brassica napus (uljana repica), koje akumuliraju teške metale u mnogo manjoj mjeri, no svojom velikom produktivnošću nadoknađuju taj nedostatak, stoga je ukupna akumulacija na kraju procesa usporediva s onom kod hiperakumulatora. ${ }^{19}$ Tako su, na primjer, Dhiman i sur. ${ }^{18}$ pokazali da se B. napus može upotrebljavati za uklanjanje cinka iz tla s vrlo visokom učinkovitošću te naknadnu proizvodnju bioetanola s visokim prinosima. Korijenski sustav osigurava ogromnu površinu koja apsorbira i akumulira vodu i hranjive tvari nužne za rast, kao i druge neesencijalne tvari. ${ }^{51}$ Kako je doseg remedijacije jednak dubini korijenja, brzorastuća stabla poput Populus spp. (topola) i Salix spp. (vrba) idealni su izbor za fitoekstrakciju uzevši u obzir njihov opsežan sustav korijenja, brzi rast, veliku biomasu te sposobnost nicanja nakon žetve. Prednost upotrebe tih stabala je manji rizik od dospijevanja teških metala u hranidbeni lanac. ${ }^{19}$ Cink i kadmij sakupljaju se u listovima tog drveća stoga je održavanje moguće žetvom lišća, ${ }^{52}$ dok je kod zbrinjavanja ostalih teških metala potrebno iskapanje i zbrinjavanje korijenja na kraju procesa. Pronađeno je i da aromatično bilje poput Mentha piperita (paprena metvica) i Lavandula angustifolia (lavanda) akumulira teške metale u nadzemnoj biomasi. Tijekom prerade biljnog materijala teški metali se izdvajaju i ne nalaze se u aromatičnim uljima kao konačnim produktima procesa. Za tla visokog stupnja onečišćenja metalima, poput onih u rudarskim i post-industrijskim područjima, zanimljiva je i fitostabilizacija koja se primjenjuje kako bi se spriječilo daljnje širenje onečišćenja. Pri odabiru biljne vrste poželjno je odabrati onu koja posje- 
duje rasprostranjen i gust korijenski sustav, budući da se imobilizacija odvija u zoni korijenja, te gust vegetativni pokrov kako bi se zaustavilo rasipanje vjetrom $\mathrm{i}$ ispiranje padalinama. Fitostabilizacija je rijetko ograničena samo na biljne vrste, već se uglavnom radi o sinergiji s mikroorganizmima iz zone korijenja. Mikroorganizmi u tlu ispuštaju organske kiseline, izvanstanične polimere od polisaharida i proteina te kelirajuće agense što potpomaže u imobilizaciji i pretvorbi teških metala u manje toksične oblike. lako na taj način teški metali ostaju u tlu, smanjuje se njihova biološka raspoloživost i toksičnost, čime se mogućnosti od onečišćenja vodenih tokova ili hranidbenog lanca drastično smanjuje. ${ }^{48}$ Primjer dobrog fitostabilizatora koji zadržava teške metale poput nikla i olova u zoni korijenja je Zea mays (kukuruz). ${ }^{53}$ Fitovolatizacija nije prikladna za većinu teških metala budući da se ne mogu prevesti u hlapljive oblike. Iznimke su živa, selenij i arsen, koji se mogu prevesti u hlapljive i često manje toksične oblike, poput dimetil selenida i živina oksida. Bez obzira na manju toksičnost produkata, fitovolatizacija se nikada ne smije provoditi u gusto naseljenim područjima i lokacijama s promjenjivim vremenskim uvjetima. ${ }^{19} \mathrm{Na}$ primjer, Typha latifolia (Širokolisni rogoz) ima veliku učinkovitost u fitovolatizaciji selenija, a Phragmites communis (trska) u fitovolatizaciji žive. ${ }^{54} \mathrm{Na}$ kraju, fitorazgradnja ne pronalazi svoju primjenu u remedijaciji tla onečišćenih teškim metalima.

\subsection{Uklanjanje organskih onečišćujućih tvari}

Za razliku od teških metala koji su biljni mikronutrijenti te se prirodno nalaze u tlima, organske onečišćujuće tvari antropogenog porijekla poput farmaceutika, pesticida, bojnih otrova i industrijskog otpada su biljkama ksenobiotici. Primjeri ksenobiotika koji završavaju u tlima i izazivaju veliku brigu su klorirani i organofosfatni pesticidi, monoaromatski i policiklički aromatski ugljikovodici (engl. polycyclic aromatic hydrocarbon - PAH), fenoli, nitroaromati, eksplozivni poliklorirani bifenili (engl. polychlorinated biphenyl - PCB) i klorirana otapala. ${ }^{55}$ Najznačajniji mehanizmi fitoremedijacije organskih onečišćujućih tvari su fitorazgradnja i rizorazgradnja. Fitorazgradnja se temelji na iskorištavanju velikog biljnog potencijala i biološke raznolikosti metaboličih putova i enzima koji mogu oksidirati, transformirati i djelomično ili potpuno razgraditi ksenobiotike. ${ }^{56}$ Prema Sandermannu ${ }^{57}$ biljke se radi mogućnosti fitorazgradnje mogu razmatrati kao zelena jetra biosfere. Tu metaforu zaslužuju jer razgrađuju onečišćujuće tvari analogno metabolizmu ksenobiotika u tijelu sisavaca. Suprotno teškim metalima koji su biljni mikronutrijenti te se unose aktivno specifičnim transporterima, unos organskih tvari odvija se pasivno, stoga su koeficijenti raspodjele i topljivost u vodi ključan preduvjet za prelazak vanjske stanične membrane i unos. ${ }^{25}$ Fitorazgradnja unutar biljaka najpogodnija je za umjereno hidrofobne organske tvari ( $\log K_{\text {Ow }}$ vrijednosti između 0,5 i 3,0), što uključuje benzen, toluen, etilbenzen, ksilen, klorirana otapala i kratkolančane alifatske ugljikovodike. Hidrofilnije kemikalije $\left(\log K_{\text {ow }}<0,5\right)$ teško prolaze kroz membrane, dok se hidrofobnije kemikalije $\left(\log K_{\text {ow }}>3\right)$ snažnije vežu za površinu korijenja i teže translociraju unutar biljaka. ${ }^{47}$ Međutim, tijekom proteklog desetljeća nekoliko istraživanja je navelo da različite biljne vrste, uglavnom iz porodice Cucurbitacea (tikvovke) mogu unositi i hidrofobnije ksenobiotike poput PCB-ova, čije se $\log K_{\text {ow }}$ vrijednosti kreću između 4,5 i 8,2 ovisno o stupnju kloriranja, polibromin-difenil etere, diklor-difenil-trikloroetan (DDT) i njegove derivate diklor-difenil-dikloroetilen i diklor-difenil-dikloroetan, heptaklor i dioksine. ${ }^{56}$ Fitorazgradnja unutar biljnih stanica može se raščlaniti na tri koraka: transformacija, konjugacija i odjeljivanje. U transformaciji ksenobiotici se modificiraju oksidacijom, redukcijom ili hidrolizom kako bi postali polarniji odnosno topljiviji u vodi, što dovodi do veće biokemijske aktivnosti. U tim reakcijama sudjeluju monooksigenaze iz skupine citokrom P-450 (CYP), karboksilesteraze, peroksidaze i lakaze. U drugoj fazi molekule se konjugiraju s endogenim šećerima i peptidima, i kao takve postaju manje toksične za biljke. Od enzima koji sudjeluju u toj fazi najznačajniji su glikotransferaze i glutation S-transferaze. U posljednjoj fazi modificirani ksenobiotici aktivno se prenose ATP vezujućim kazetnim transporterima i pohranjuju u vakuolama ili ugrađuju u staničnim stjenkama. ${ }^{19,25}$ Osim tog općenitog objašnjenja detoksikacije u tri slijedna koraka, prisutni su i mnogo specifičniji metabolički putovi koji se aktiviraju ovisno o prirodi onečišćujuće tvari i biljnoj vrsti. Neki metabolički putovi i enzimi za različite pesticide, eksplozive i sintetičke boje dosad su već otkriveni i poznati, no metabolizam mnogih ksenobiotika i dalje je nejasan a moguće interferencije s primarnim i sekundarnim biljnim metabolitima su nepoznate. Iz tog razloga iznimno je važno otkriti detaljne metaboličke putove pojedinačnih ksenobiotika kako bi se proces što bolje kontrolirao, čime bi se izbjeglo moguće oslobađanje toksičnih metabolita te poboljšala učinkovitost i sigurnost fitoremedijacije. ${ }^{56}$ Neki od mnogobrojnih uspješnih primjera fitorazgradnje uključuju upotrebu topole (Populus spp.) u remedijaciji tla onečišćenog 2,4,6-trinitrotoluenom (TNT), kao predstavnikom eksploziva i trikloretilenom, kao predstavnikom kloriranih otapala. Razbijanje molekula TNT-a vrši se pomoću nitroreduktaze i lakaze, dok dehalogenaze kataliziraju razgradnju trikloretilena na kloridne ione, ugljikov dioksid i vodu. ${ }^{47}$ Aken i sur. ${ }^{58}$ izolirali su iz topole Methylobacterium sp. endofitsku bakteriju s mogućnošću razgradnje TNT-a. Time su ukazali na mogućnost da u fitorazgradnji sudjeluju i biljni endosimbionti, odnosno bakterije koje žive unutar biljaka. Od velikog interesa za fitoremedijaciju su i PAH-ovi koji se nalaze na listi prioritetnih onečišćujućih tvari. Procijenjeno je da se $90 \%$ okolišnog opterećenja PAH-ovima nalazi upravo u tlima, budući da se jednom kad dospiju u tlo zadržavaju godinama uslijed velike rezistentnosti i hidrofobnosti. ${ }^{59}$ Neke vrste trava poput Cyanodon dactylon (prstasti troskot), Festuca arundinacea (trstikasta vlasulja), Festuca rubra (crvena vlasulja) i Melilotus officinalis (žuti kokotac) poznate su da uklanjaju PAH-ove. ${ }^{60}$ Ipak, $\log K_{\text {ow }}$ vrijednosti tih spojeva prelaze 3 , što ih čini mnogo pogodnijim izborom za rizorazgradnju nego fitorazgradnju. Rizorazgradnja ili fitostimulacija se zasniva na metabolizmu rizosferskih mikroorganizama poboljšanom korijenskim eksudatima i opskrbom kisikom. U području korijenja može se pronaći povećan broj i raznolikost vrsta mikroorganizama (bakterija i gljiva), pa tako izvori navode da gustoća naseljenosti mikroorganizama u rizosferi može biti do 4 reda veličine veća od populacije u okolnom tlu. Taj takozvani efekt rizosfere postoji zahvaljujući različitim fizičkim i kemijskim utjecajima korijenja, poput izmjene plinova, ovlaživanja tla i rizodepozicije, što okolno tlo čini 
pogodnijim staništem za mikroorganizme. ${ }^{25,47}$ Rizodepozicija je proces kojim biljke putem korijenja ispuštaju šećere, aminokiseline i organske kiseline u okolno tlo. U fitoremedijaciji je to od iznimne važnosti za one onečišćujuće tvari koje ne mogu biti upotrijebljene kao primarni izvor ugljika u metabolizmu mikroorganizama jer bi energetska bilanca bila negativna. U kometabolizmu lako razgradljivih biljnih eksudata i organskih onečišćujućih tvari energetska bilanca postaje pozitivna, ${ }^{25}$ što ustvari znači da biljni eksudati služe kao stimulansi i inicijatori za razgradnju kompleksnijih onečišćenja. Osim biljnih eksudata, i mrtva biljna biomasa može potaknuti rizorazgradnju. Narančina kora, borove iglice i bršljanovo lišće bogati su terpenima i flavonoidima, koji su ponekad strukturni analozi ksenobiotika i mogu se upotrijebiti za poticanje rizorazgradnje PCB-ova. ${ }^{56}$ Važnost rizobakterija u procesu rizorazgradnje pokazana je $\mathrm{i}$ u mnogobrojnim radovima gdje je bioaugmentacijom poboljšana sveukupna učinkovitost procesa remedijacije, poput onog gdje je dodatkom Bacillus altitudinis u tlo plave djeteline (Medicago sativa) ubrzano uklanjanje PAH-ova i postignuta visoka učinkovitost. ${ }^{61}$ Primjer korisne rizorazgradnje u uklanjanju PAH-ova je tropsko drvo Sebastiania commersoniana, koje se može upotrijebiti u autohtonom staništu u Južnoj Americi za zbrinjavanje onečišćenih tala od aktivnosti povezanih s naftnom industrijom. ${ }^{62}$ Rizorazgradnja je osim za PAH-ove vrlo uspješna i PCB-ove, dizel i etilen glikol. ${ }^{47}$

\section{Biostimulacija i dodatci za poboljšavanje procesa}

Učinkovitost fitoremedijacije ovisi o odabranoj biljnoj vrsti i značajkama tla, karakteristikama onečišćujućih tvari, zoni korijenja i okolišnim uvjetima. Također, kako bi se procesi fitoremedijacije inicirali, ubrzali ili poboljšali, moguća je upotreba dodataka za poboljšanje biološke dostupnosti i unosa onečišćujućih tvari (slika 2). ${ }^{54}$
Tako se u fitoekstrakciji unos i translokacija teških metala u tragovima mogu povećati dodatkom etilendiamintetraoctene kiseline (EDTA) ili etilendiamin- $N, N^{\prime}$-disukcinske kiseline (EDDS), budući da kelatna sredstva mogu 1000 puta povećati razinu dostupnih metala u tlu..$^{47,63}$ Suprotno dodatku kelatnih sredstava, dodatkom pepela i zeolita može se znatno smanjiti bioraspoloživost metala biljkama, čime se ograničava njihov unos i posljedična toksičnost za biljke. ${ }^{47}$ Takvi dodatci korisni su u slučaju fitostabilizacije, kada je željeni ishod imobilizacija metala u tlu. Analogno uporabi kelatnih agensa u fitoekstrakciji teških metala, unos hidrofobnih organskih tvari može se povećati dodatkom površinski aktivnih tvari. lako brojne biljke i mikroorganizmi sami po sebi proizvode biosurfaktante, upotreba kemijskih surfaktanata služi kao dodatna stimulacija i ubrzavanje metabolizma onečišćujućih tvari. ${ }^{25,63}$ Ipak, sintetički dodatci nisu uvijek najbolje rješenje. Kelirajuća sredstva trebaju biti oprezno dozirana i njihova primjena kontrolirana, budući da njihova neselektivna priroda prema metalima može znatno smanjiti bioraspoloživost alkalnih kationa kalcija i magnezija. Također, EDTA može imati loš utjecaj na biljni rast i razvoj, slabo je biorazgradljiva te postoji rizik od dospijevanja u okolni okoliš ispiranjem. ${ }^{63}$ Postoje radovi ${ }^{63-66}$ koji ukazuju na mogućnost upotrebe ekološki prihvatljivih dodataka za fitoremedijaciju kako teških metala, tako i organskih onečišćujućih tvari. Npr., u fitoekstrakciji teških metala može se rabiti nusprodukt nakon ekstrakcije šećera i fermentacije šećerne repe s Aspergillus niger. Taj lignocelulozni materijal organski je dodatak bogat polisaharidima i fosforom. Utvrđeno je da njegova primjena poboljšava fitoekstrakciju željeza, cinka, kadmija, kroma i nikla iz tla pomoću bijele djeteline (Trifolium repens) i motra (Crithmum maritimum). Primjer za stimulaciju procesa rizorazgradnje organskih onečišćujućih tvari je dodatak melase, nusprodukta pri proizvodnji šećera, koji pospješuje učinkovitost razgradnje eksploziva heksogena. ${ }^{63}$ Dobar primjer za tla onečišćena mješavinama teških metala i naftnih ugljikovodika je dodatak huminskih kiselina u tlima remediranim s Brassica campestris (repa), F. arundinacea i Helianthus annuus (jednogodišnji suncokret).

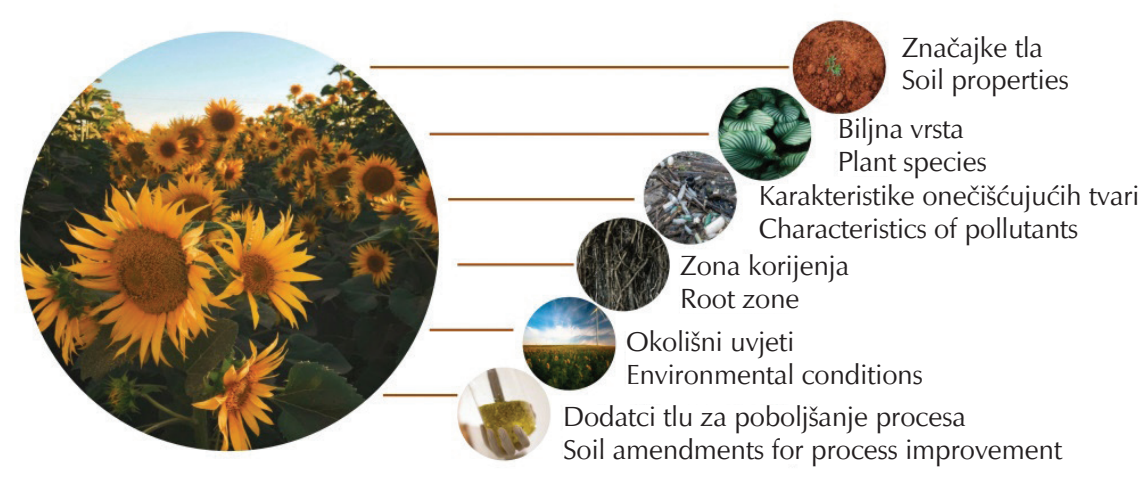

Slika 2 - Faktori koji utječu na učinkovitost fitoremedijacije

Fig. 2 - Factors affecting phytoremediation efficiency 
Huminske kiseline imaju trostruki učinak: povećavaju biološku dostupnost naftnih ugljikovodika, potiču mikrobnu aktivnost te stvaraju komplekse s teškim metalima čime, najvjerojatnije, smanjuju njihovu toksičnost za biljke. ${ }^{67}$

\section{Transgenične biljke u fitoremedijaciji}

Napredak u području fitoremedijacije posljednjih je godina impresivan zahvaljujući sve boljem razumijevanju i manipuliranju temeljnim biokemijskim procesima unutar biljaka i u rizosferi. Istraživanja su okrenuta prema radu na modernim molekulskim tehnologijama s velikim biotehnološkim potencijalom. ${ }^{68}$ Začetak ideje o transgeničnim biljkama za fitoekstrakciju teških metala nastao je usporedbom fizioloških i molekularnih analiza hiperakumulatora i srodnih ne-hiperakumulatora. Gotovo sve do danas poznate vrste hiperakumulatora metala su endemske vrste, odnosno pronađene su na specifičnim tlima bogatim metalima. To upućuje na činjenicu da je hiperakumulacija zapravo vrlo važna fiziološka prilagodba na stres teških metala i jedna od manifestacija rezistentnosti na metale. Otkriveno je da se većina ključnih koraka u hiperakumulaciji ne provodi zahvaljujući genima specifičnim za te vrste, već zahvaljujući različitoj regulaciji i ekspresiji gena koji se nalaze u objema vrstama. Ključnu ulogu u unosu, translokaciji i pohranjivanju u vakuolama ima prekomjerna ekspresija gena koji kodiraju već spomenute transmembranske transportere. Novija istraživanja pružaju snažnu osnovu za modificiranje brzorastućih organizama kako bi nadoknadili osobine hiperakumulacije teških metala. ${ }^{19}$ Dushenkov $i$ sur. ${ }^{69}$ pokazali su kako biljni hibrid proizveden asimetričnom somatskom hibridizacijom kombinira vrijedne osobine obaju biljaka. Hibrid je od $B$. juncea naslijedio veliku stopu proizvodnje biomase, a toleranciju teških metala i sposobnost akumulacije cinka i nikla od Thlaspi caerulescens (čestika). Takva istraživanja ne zaustavljaju se na teškim metalima, već su značajni napreci postignuti i za organske onečišćujuće tvari. Budući da su biljke autotrofni organizmi i ne rabe organske tvari kao izvor ugljika i energije, one uobičajeno nemaju kataboličke enzime potrebne za potpunu mineralizaciju organskih tvari do ugljikova dioksida i vode. Istraživanja su usmjerena ka upotrebi rekombinantne DNK tehnologije i implementacije specifičnih gena iz heterotrofnih organizama u biljke s ciljem povećanja tolerancije i metabolizma organskih tvari. Tako postoje primjeri zavidne uspješnosti u razgradnji organskih ksenobiotika, poput implementacije bakterijske pentaeritritol-tetranitrat reduktaze u Nicotiana tabacum (duhan) za razgradnju eksploziva te implementacije nitroreduktaze iz Escherichia coli u Arabidopsis thaliana (talijin uročnjak) za razgradnju TNT-a. ${ }^{47}$

\section{Budućnost fitoremedijacije}

Kako je brojnost populacije u stalnom i brzom porastu, zahtjevi za hranom i vodom dobre kvalitete proporcionalno rastu. Prema trenutačnim predviđanjima, do 2050. godine potreba za proizvodnjom hrane porast će za $60 \%$ u odnosu na 2009. godinu na globalnoj razini, a u zemljama u razvoju za čak $100 \%$. Budući da $95 \%$ proizvodnje hrane ovisi o tlima, produktivnost tala je kamen temeljac ljud- skog razvoja i neraskidivo je povezana s ljudskom sigurnošću i zdravljem. ${ }^{2}$ Pokazano je kako onečišćena tla mogu uroditi plodom, no količina akumuliranih teških metala te razgradnih produkata u biljnim izbojcima čini zdravstvenu kvalitetu tih plodova upitnom. Teški metali mogu dospjeti u ljudsku prehranu izravno putem biljne ishrane ili neizravno preko mesa zbog svojstva biomagnifikacije. Dostupnost i stabilnost opskrbe hranom važno je pitanje ljudske budućnosti, zbog čega odgovorno gospodarenje tlima treba zauzeti prioritetno mjesto u sadašnjosti. Prema procjeni u izvješću Europske komisije iz 2018. godine, broj onečišćenih područja u Europskoj uniji je oko 2,8 milijuna, što odgovara 3,6 područja s onečišćenim tlom po jednom kvadratnom kilometru. ${ }^{70}$ Krajem 2017. godine Skupština Programa Ujedinjenih naroda za okoliš usvojila je rezoluciju kojom se poziva na ubrzano djelovanje i suradnju država članica za rješavanje i upravljanje onečišćenjem tla. ${ }^{2}$ lako se tijekom proteklih 20-ak godina fitoremedijacija uspješno primjenjuje za obradu umjereno onečišćenih tala, sedimenata i pitkih vodonosnika, primjena tih tehnologija u većem mjerilu i dalje je na mnogo nižim razinama nego što bi trebala biti. Potrebno je ulagati resurse u nova istraživanja s ciljem boljeg razumijevanja procesa te nadilaženja nedostataka ali i raditi na stvaranju slike o fitoremedijaciji u očima javnosti i krojača politike kao sve zrelije i učinkovitije tehnologije. ${ }^{56}$ Vjerojatno je da će fitoremedijacija i transgenične biljke igrati veliku ulogu u budućnosti po pitanju remedijacije tala i pitanju ljudske opskrbe hranom. Osim zakonskih okvira koji upućuju na očuvanje i remedijaciju tala, znanstvena istraživanja u novije vrijeme okrenuta su istraživanju transgeničnih biljaka koje se mogu upotrijebiti za sigurnu poljoprivrednu proizvodnju na tlima onečišćenim teškim metalima. Spomenuto je da rezistentnost biljaka na teške metale uključuje izbjegavanje unosa teških metala u nadzemna biljna tkiva. Biljke izolatori metala (engl. metal excluders) su one biljne vrste koje akumuliraju teške metale iz tla u korijenju, ali ograničavaju njihov prijenos i ulazak u nadzemna tkiva. Identifikacija gena koji omogućuju biljkama izolatorima da ograniče unos teških metala te implementacija tih gena u usjeve hrane mogao bi biti siguran način za uzgoj biljne hrane na onečišćenim zemljištima. ${ }^{19}$

\section{Zaključak}

Tla čine osnovnu sastavnicu okoliša čija je kvaliteta izravno povezana s ljudskom sigurnošću i zdravljem te održivosti ekosustava. U mnogim područjima diljem svijeta tla i dalje pate od lošeg upravljanja ili njegovih posljedica u prošlosti, kada su se smatrala univerzalnim odvodom za onečišćujuće tvari. Fitoremedijacija je učinkovita tehnologija in situ koja se primjenjuje za remedijaciju tala onečišćenih organskim tvarima, teškim metalima ili njihovim kompleksnim mješavinama. Postoji velik broj istraživanja koja dokazuju da fitoekstrakcija i fitostabilizacija imaju najveći potencijal u slučaju onečišćenja teškim metalima, a fitorazgradnja i rizorazgradnja u slučaju organskih onečišćujućih tvari. Pri odabiru biljne vrste za sanaciju određenog područja potrebno je razmotriti tip, svojstva i rasprostranjenost onečišćenja te okolišne i klimatske uvjete. Iniciranje, ubrzavanje i poboljšavanje procesa fitoremedijacije moguće je 
upotrebom kelirajućih sredstava, surfaktanata ili bioloških stimulansa procesa. Kako bi fitoremedijacija postala potpuno zrela tehnologija za široke primjene i implementacije u većem mjerilu, potrebno je riješiti još mnoga pitanja. Ograničavanje rizika od ulaska onečišćujućih tvari u hranidbeni lanac od ključne je važnosti, stoga su potrebna istraživanja usmjerena u poznavanje sudbine ksenobiotika i njihovih razgradnih produkata po svršetku procesa. Budućnost fitoremedijacije leži u poznavanju genetičkih, molekularnih i staničnih mehanizama te njihovoj manipulaciji u svrhu poboljšanja procesa. Potrebno je raditi na stvaranju slike o fitoremedijaciji u očima javnosti i krojača politike kao sve zrelije i kompetentnije tehnologije kako bi se dodatni resursi usmjerili u njezina istraživanja i implementacije provjerenih sustava.

\section{ZAHVALA}

Autori zahvaljuju Hrvatskoj zakladi za znanost za financiranje stipendije za doktorat Nevene Milčić.

\section{Popis kratica \\ List of abbreviations}

\begin{tabular}{|c|c|}
\hline PAH & $\begin{array}{l}\text { - policiklički aromatski ugljikovodici } \\
\text { - polycyclic aromatic hydrocarbons }\end{array}$ \\
\hline PCB & $\begin{array}{l}\text { - poliklorirani bifenili } \\
\text { - polychlorinated biphenyls }\end{array}$ \\
\hline DDT & $\begin{array}{l}\text { - diklor-difenil-trikloroetan } \\
\text { - dichloro-diphenyl-trichloroethane }\end{array}$ \\
\hline TNT & $\begin{array}{l}\text { - 2,4,6-trinitrotoluen } \\
\text { - 2,4,6-trinitrotoluene }\end{array}$ \\
\hline$K_{\text {ow }}$ & $\begin{array}{l}\text { - koeficijent raspodjele tvari u n-oktanolu i vodi } \\
\text { - octanol-water partition coefficient }\end{array}$ \\
\hline EDTA & $\begin{array}{l}\text { - etilendiamintetraoctena kiselina } \\
\text { - ethylenediaminetetraacetic acid }\end{array}$ \\
\hline EDDS & $\begin{array}{l}\text { - etilendiamin- } N, N^{\prime} \text {-disukcinska kiselina } \\
\text { - ethylenediamine- } N, N^{\prime} \text {-disuccinic acid }\end{array}$ \\
\hline $\begin{array}{l}\text { DNK/ } \\
\text { DNA }\end{array}$ & $\begin{array}{l}\text { - deoksiribonukleinska kiselina } \\
\text { - deoxyribonucleic acid }\end{array}$ \\
\hline
\end{tabular}

\section{Literatura \\ References}

1. N. Marmiroli, M. Marmiroli, E. Maestri, Phytoremediation and phytotechnologies: a review for the present and the future, u I. Twardowska, H. E. Allen, M. M. Häggblom and S. Stefaniak (ur.), Soil and Water Pollution Monitoring, Protection and Remediation. Vol. 6, Springer, Netherlands, 2006., str. 403-416.

2. N. Rodríguez, M. Mclaughlin, D. Pennock, What is soil pollution, u N. Rodríguez, M. McLaughlin and D. Pennock (ur.), Soil Pollution: A Hidden Reality. FAO, Rome, Italy, 2018., str. $1-41$.

3. I. A. Mirsal, The Origin of Soil, u I. A. Mirsal (ur.), Soil Pollution: Origin, Monitoring \& Remediation. Springer-Verlag Berlin Heidelberg, 2008., str. 1-11.
4. D. W. Blowes, C. J. Ptacek, J. L. Jambor, C. G. Weisener, The Geochemistry of Acid Mine Drainage, u H. D. Holland and K. K. Turekian (ur.), Treatise on Geochemistry. Vol. 9, Elsevier, Amsterdam, Netherlands, 2003., str. 149-204.

5. A. Balasubramanian, Soil Forming Processes, Technical Report published via University of Mysore (2017), doi: https:// doi.org/10.13140/RG.2.2.34636.00644.

6. K. Fatima, A. Imran, M. Saeed, M. Afzal, Plant-Bacteria Synergism: An Innovative Approach for the Remediation of Crude Oil-Contaminated Soils, Soil. Environ. 36 (2) (2017) 93-113, doi: https://doi.org/10.25252/SE/17/51346.

7. S. Greipsson, Phytoremediation, Nature Education Knowledge 3 (10) (2011)

8. H. Ali, E. Khan, M. A. Sajad, Phytoremediation of heavy metals - Concepts and applications, Chemosphere 91 (7) (2013) 869-881, doi: https://doi.org/10.1016/j. chemosphere.2013.01.075.

9. A. Guittonny-Philippe, M. E. Petit, V. Masotti, Y. Monnier, L. Malleret, B. Coulomb, I. Combroux, T. Baumberger, J. Viglione, I. Laffont-Schwob, Selection of wild macrophytes for use in constructed wetlands for phytoremediation of contaminant mixtures, J. Environ. Manage. 147 (2015) 108-123, doi: https://doi.org/10.1016/j.jenvman.2014.09.009.

10. D. E. Salt, M. Blaylock, N. Kumar, V. Dushenkov, B. D. Ensley, I. Chet, I. Raskin, Phytoremediation: A Novel Strategy for the Removal of Toxic Metals from the Environment Using Plants, Bio/Technol. 13 (5) (1995) 468-74, doi: https://doi. org/10.1038/nbt0595-468.

11. J. Bishop, Phytoremediation: A New Technology Gets Ready to Bloom, Environ. Solutions 10 (4) (1997).

12. B. Suresh, R. Gokare, Phytoremediation - A Novel and Promising Approach for Environmental Clean-Up, Crit. Rev. Biotechnol. 24 (2-3) (2004) 97-124, doi: https://doi. org/10.1080/07388550490493627.

13. B. Robinson, S. Green, T. Mills, B. Clothier,M. van der Velde, R. Laplane, L. Fung, M. Deurer, S. Hurst, T. Thayalakumaran, C. Dijssel, Phytoremediation: using plants as biopumps to improve degraded environments, Soil. Res. 41 (3) (2003) 599-611, doi: https://doi.org/10.1071/SR02131.

14. S. Mccutcheon, S. Rock, Phytoremediation: State of the Science Conference and Other Developments, Int. J. Phytoremediat. 3 (1) (2001) 1-11, doi: https://doi. org/10.1080/15226510108500047.

15. F. Were, G. Wafula, S. Wairungu, Phytoremediation Using Bamboo to Reduce the Risk of Chromium Exposure from a Contaminated Tannery Site in Kenya, J. Health. Pollut. 7 (16) (2017) 12-25, doi: https://doi.org/10.5696/2156-96147.16.12.

16. M. N. V. Prasad, Phytoremediation of Metal-Polluted Ecosystems: Hype for Commercialization, Russ. J. Plant. Physiol. 50 (5) (2003) 686-701, doi: https://doi. org/10.1023/A:1025604627496.

17. V. Sheoran, A. S. Sheoran, P. Poonia, Phytomining: A review, Miner. Eng. 22 (12) (2009) 1007-1019, doi: https://doi. org/10.1016/j.mineng.2009.04.001.

18. S. S. Dhiman, C. Selvaraj, J. Li, R. Singh, X. Zhao, D. Kim, J. Y. Kim, Y. C. Kang, J. K. Lee, Phytoremediation of metal-contaminated soils by the hyperaccumulator canola (Brassica napus L.) and the use of its biomass for ethanol production, Fuel 183 (2016) 107-114, doi: https://doi.org/10.1016/j. fuel.2016.06.025.

19. A. P. Pinto, A. de Varennes, R. Fonseca, D. Martins Teixeira, Phytoremediation of Soils Contaminated with Heavy Metals: Techniques and Strategies, u A. Ansari, S. Gill, R. Gill, G. Lanz and L. Newman, Phytoremediation: Management of 
Environmental Contaminants. Vol. 1, Springer, Switzerland, 2015., str. 133-158.

20. A. Koźmińska, A. Wiszniewska, E. Hanus-Fajerska, E. Muszyńska, Recent strategies of increasing metal tolerance and phytoremediation potential using genetic transformation of plants, Plant Biotechnol. Rep. 12 (1) (2018) 1-14, doi: https://doi.org/10.1007/s11816-017-0467-2.

21. A. Dadrasnia, N. Shahsavari, C. Emenike, Remediation of Contaminated Sites, u V. Kutcherov and A. Kolesnikov, Hydrocarbon, IntechOpen, London, United Kingdom, 2013., str. 65-82.

22. B. V. Tangahu, S. R. S. Abdullah, H. Basri, M. Idris, N. Anuar, M. Mukhlisin, A Review on Heavy Metals (As, Pb, and $\mathrm{Hg}$ ) Uptake by Plants Through Phytoremediation, Int. J. Chem. Eng. 2011 (2011) 1-31, doi: https://doi. org/10.1155/2011/939161.

23. N. S. Bolan, J. H. Park, B. Robinson, R. Naidu, K. Y. Huh, Phytostabilization: A Green Approach to Contaminant Containment, Adv. Agron. 112 (2011) 145-204, doi: https://doi. org/10.1016/B978-0-12-385538-1.00004-4.

24. A. T. Jan, A. Ali, Q. Haq, Phytoremediation: A Promising Strategy on the Crossroads of Remediation, u K. Hakeem, M. Sabir, M. Ozturk, A. Mermut, Soil Remediation and Plants: Prospects and Challenges, Elsevier, Netherlands, 2015., str. 63-84.

25. T. G. Reichenauer, J. J. Germida, Phytoremediation of Organic Contaminants in Soil and Groundwater, ChemSusChem 1 (8-9) (2008) 708-717, doi: https://doi.org/10.1002/ CSSC. 200800125

26. I. Alkorta, C. Garbisu, Phytoremediation of organic contaminants in soils, Bioresour. Technol. 79 (3) (2001) 273-276, doi:https://doi.org/10.1016/S0960-8524(01)00016-5.

27. M. Zhran, S. M. Lotfy, Phytoremediation of Contaminated Soil with Cobalt and Chromium, J. Geochem. Explor. 144 (2014) 367-373, doi: https://doi.org/10.1016/j.gexplo.2013.07.003.

28. H. I. El Kassas, M. Sharaf, A. M. Niazy Abdou, Phytoremediation of zinc and copper contaminated soils by using different hyper accumulating plants, J. Environ. Sci. 7 (2003) 1-23.

29. K. A. Alaboudi, B. Ahmed, G. Brodie, Phytoremediation of Pb and $\mathrm{Cd}$ contaminated soils by using sunflower (Helianthus annuus) plant, Ann. Agric. Sci. 63 (1) (2018) 123-127, doi: https://doi.org/10.1016/j.aoas.2018.05.007.

30. A. C. Alvarenga, R. A. Sampaio, G. P. Pinho, P. H. S. Cardoso, I. Sousa, M. H. C. Barbosa, Phytoremediation of Chlorobenzenes in Sewage Sludge Cultivated with Pennisetum Purpureum at Different Times, R. Bras. Eng. Agríc. Ambiental 21 (8) (2017) 537-578, doi: https://doi.org/10.1590/18071929/agriambi.v21n8p573-578.

31. P. E. Ndimele, C. A. Kumolu-Joh, K. Chukwuka, C. C. Ndimele, O. A. Ayorinde, O. R. Adaramoye. Phytoremediation of Iron (Fe) and Copper (Cu) by Water Hyacinth (Eichhornia Crassipes (Mart.) Solms), Trends. Appl. Sci. Res. 9 (9) (2014) 485-493, doi: https://doi.org/10.3923/tasr.2014.485.493.

32. P. Saha, O. Shinde, S. Sarkar, Phytoremediation of Industrial Mines Wastewater Using Water Hyacinth, Int. J. Phytoremediation 19 (1) (2017) 87-96, doi: https://doi.org/10.1080/15 226514.2016.1216078.

33. V. J. Odjegba, I. O. Fasidi, Phytoremediation of heavy metals by Eichhornia crassipes, Environmentalist 27 (3) (2007) 349-355, doi: https://doi.org/10.1007/s10669-007-9047-2.

34. M. E. Hosman, S. Elfeky, M. I. Elshahawy, E. M. Shaker, Mechanism of Phytoremediation Potential of Flax (Linum Usitatissimum L.) to $\mathrm{Pb}, \mathrm{Cd}$ and $\mathrm{Zn}$, Asian J. Plant. Sci. Res. 7 (4) (2017) 30-40.
35. C. Jasiewicz, J. Antonkiewicz, Assessment of common flax ( $\mathrm{Li}-$ num usitatissimum L.) usability for phytoremediation of soil contaminated with heavy metals, Ecol. Chem. Eng. S. 10 (9) (2003) 901-907.

36. Amna, J. H. Syed, S. Masood, M. F. Munis, H. J. Chaundhary, Phyto-Extraction of Nickel by Linum Usitatissimum in Association with Glomus Intraradices, Int. J. Phytoremediation 17 (10) (2015) 981-987, doi: https://doi.org/10.1080/1522651 4.2014.989311.

37. V. Angelova, R. Ivanova, J. M. Todorov, K. Ivanov, Potential of rapeseed (Brassica napus L.) for phytoremediation of soils contaminated with heavy metals, J. Environ. Prot. Ecol. 18 (2) (2017) 468-478.

38. M. Turan, A. Esringü, Phytoremediation Based on Canola (Brassica Napus L.) and Indian Mustard (Brassica Juncea L.) Planted on Spiked Soil by Aliquot Amount of $\mathrm{Cd}, \mathrm{Cu}, \mathrm{Pb}$, and Zn, Plant. Soil. Environ. 53 (1) 7-15, doi: https://doi. org/10.17221/3188-PSE.

39. M. Rafati, N. Khorasani, F. Moattar, A. Shirvany, F. Moraghebi, S. Monfared, Phytoremediation Potential of Populus Alba and Morus Alba for Cadmium, Chromuim and Nickel Absorption from Polluted Soil, Int. J. Environ. Res. 5 (4) (2011) 961-970, doi: https://doi.org/10.22059/ijer.2011.453.

40. V. Castro Rodriguez, A. Garcia-Gutierrez, J. Canales, R. A. Cañas, E. Kirby, A. Avila, F. M. Cánovas, Poplar Trees for Phytoremediation of High Levels of Nitrate and Applications in Bioenergy, Plant Biotechnol. J. 14 (2016) 299-312, doi: https://doi.org/10.1111/pbi.12384.

41. S. N. Singh, S. Mishra, Phytoremediation of TNT and RDX, u S. N. Singh, Biological Remediation of Explosive Residues, Vol. 112., Springer, Switzerland, 2014., str. 371-392.

42. T. Spriggs, M. K. Banks, A. Schwab, Phytoremediation of Polycyclic Aromatic Hydrocarbons in Manufactured Gas PlantImpacted Soil, J. Environ. Qual. 34 (5) (2005) 1755-62, doi: https://doi.org/10.2134/jeq2004.0399.

43. R. E. Meggo, J. L. Schnoor, Cleaning Polychlorinated Biphenyl (PCB) Contaminated Garden Soil by Phytoremediation, J. Environ. Sci. 1 (1) (2013) 33-52.

44. J. Janssen, N. Weyens, S. Croes, B. Beckers, Phytoremediation of Metal Contaminated Soil Using Willow: Exploiting Plant-Associated Bacteria to Improve Biomass Production and Metal Uptake, Int. J. Phytoremediat. 17 (11) (2015) 1123-1136, doi: https://doi.org/10.1080/15226514.2015.1 045129 .

45. F. Shah, N. Ahmad, K. R. Masood, J. Peralta-Videa, F. Ahmad, Heavy Metal Toxicity in Plants, u: M. Ashraf, M. S. A. Ahmad, M. Ozturk, Plant Adaptation and Phytoremediation, Springer, Netherlands, 2010., str. 71-97.

46. H. Ali, E. Khan, Trophic transfer, bioaccumulation, and biomagnification of non-essential hazardous heavy metals and metalloids in food chains/webs - Concepts and implications for wildlife and human health, Hum. Ecol. Risk. Assess. 24 (2018) 1-25, https://doi.org/10.1080/10807039.2018.1469 398.

47. J. H. Lee, An overview of phytoremediation as a potentially promising technology for environmental pollution control, Biotechnol. Bioprocess. Eng. 18 (3) (2013) 431-439, doi: https://doi.org/10.1007/s12257-013-0193-8.

48. M. Sivaramakrishnan, N. Sivarajasekar, J. S. Vivek, T. Paramasivan, Mu. Naushad, J. Prakashmaran, V. Gayathri, O. K. Al-Duaij, Phytoremediation of Heavy Metals: Mechanisms, Methods and Enhancements, Environ. Chem. Lett. 16 (4) (2018) 1339-1359, doi: https://doi.org/10.1007/s10311018-0762-3.

49. R. R. Brooks, J. Lee, R. D. Reeves, T. Jaffre, Detection of nickeliferous rocks by analysis of herbarium specimens of indi- 
cator plants, J. Geochemical Explor. 7 (1977) 49-57, doi: https://doi.org/10.1016/0375-6742(77)90074-7.

50. S. S. Gill, N. A. Anjum, I. Ahmad, P. Thangavel, G. Sridevi, M. Pacheco, A. C. Duarte, S. Umar, N. A. Khan, M. E. Pereira, Metal Hyperaccumulation and Tolerance in Alyssum, Arabidopsis and Thlaspi: An Overview, u N. A. Anjum, I. Ahmad, M. E. Pereira, A. C. Duarte, S. Umar, N. Khan, The Plant Family Brassicaceae: Contribution Towards Phytoremediation, Springer, Netherlands, 2012., str. 99-137.

51. K. Sureshvarr, D. B. Bharathiraja, M. Jayakumar, J. Jayamuthunagai, L. Balaji, Removal of Azo Dye Compounds from Paper Industries Wastes Using Phytoremediation Methodology, Int. J. Chem. Sci. 8 (2010) 687-700.

52. R. Unterbrunner, M. Puschenreiter, P. Sommer, G. Wieshammer, P. Tlustoš, M. Zupan, W. W.Wenzel, Heavy metal accumulation in trees growing on contaminated sites in Central Europe, Environ. Pollut. 148 (1) (2007) 107-114, doi: https://doi.org/10.1016/j.envpol.2006.10.035.

53. T. Yathavakulasingam, M. T. Mikunthan, M. Vithanage, Acceleration of Lead Phytostabilization by Maize (Zea Mays) in Association with Gliricidiasepium Biomass, Int. J. Environ. Agric. Res. 2 (5) (2016) 16-21.

54. L. Liang, W. Liu, Y. Sun, X. Huo, S. Li, Q. Zhou, Phytoremediation of Heavy Metal-Contaminated Saline Soils Using Halophytes: Current Progress and Future Perspectives, Environ. Rev. 25 (3) (2016) 269-281, doi: https://doi.org/10.1139/ er-2016-0063.

55. S. G. Ibañez, C. E. Paisio, A. L. W. Oller, M. A. Talano, P. S. González, M. I. Medina, E. Agostini, Overview and New Insights of Genetically Engineered Plants for Improving Phytoremediation u A. Ansari, S. Gill, R. Gill, G. Lanz and L. Newman, Phytoremediation: Management of Environmental Contaminants, Vol. 1, Springer, Switzerland, 2015., str. 133-158.

56. J. P. Schwitzguébel, Phytoremediation of soils contaminated by organic compounds: hype, hope and facts, J. Soils Sediments. 17 (5) (2017) 1492-1502, doi: https://doi. org/10.1007/s11368-015-1253-9.

57. H. Sandermann, Plant Metabolism of Xenobiotics, Trends. Biochem. Sci. 17 (2) (1992) 82-84, doi: https://doi. org/10.1016/0968-0004(92)90507-6.

58. B. Van Aken, J. M. Yoon, J. L. Schnoor, Biodegradation of nitro-substituted explosives 2,4,6-trinitrotoluene, hexahydro-1,3,5-trinitro-1,3,5-triazine, and octahydro-1,3,5,7-tetranitro-1,3,5-tetrazocine by a phytosymbiotic Methylobacterium sp. associated with poplar tissues (Populus deltoides), Appl. Environ. Microbiol. 70 (1) (2004) 508-517, doi: https://doi.org/10.1128/aem.70.1.508-517.2004.

59. R. D'Souza, M. Varun, A. Lakhani, V. Singla, M. S. Paul, PAH Contamination of Urban Soils and Phytoremediation $u$ A. Ansari, S. Gill, R. Gill, G. Lanz and L. Newman, Phytoremediation: Management of Environmental Contaminants, Vol.
1, Springer, Switzerland, 2015., str. 133-158.

60. A. K. Haritash, C. P. Kaushik, Biodegradation aspects of Polycyclic Aromatic Hydrocarbons (PAHs): A review, J. Hazard. Mater. 169 (1) (2009) 1-15, doi: https://doi.org/10.1016/j. jhazmat.2009.03.137.

61. A. Bano, A. Shahzad, S. Siddiqui, Rhizodegradation of Hydrocarbon from Oily Sludge, J. Bioremediat. Biodegrad. 6 (3) (2015) 1-11, doi: https://doi.org/10.4172/21556199.1000289

62. D. Ramos, L. Maranho, A. Godoi, M. A. Carvalho, L. Lacerda, E. Vasconcelos, Petroleum Hydrocarbons Rhizodegradation by Sebastiania Commersoniana (Baill.) L. B. SM. \& Downs, Water Air Soil Pollut. 9 (3) (2009) 293-302, doi: https://doi. org/10.1007/s11267-009-9208-z.

63. A. Wiszniewska, E. Hanus-Fajerska, E. Muszyńska, K. Ciarkowska, Natural Organic Amendments for Improved Phytoremediation of Polluted Soils: A Review of Recent Progress, Pedosphere 26 (1) (2016) 1-12, doi: https://doi. org/10.1016/S1002-0160(15)60017-0.

64. A. Grobelak, Organic Soil Amendments in the Phytoremediation Process. u A. Ansari, S. Gill, R. Gill, G. Lanz and L. Newman, Phytoremediation: Management of Environmental Contaminants, Vol. 1, Springer, Switzerland, 2015., str. 21-39.

65. P. Shrestha, K. Bellitürk, J. Gorres, Phytoremediation of Heavy Metal-Contaminated Soil by Switchgrass: A Comparative Study Utilizing Different Composts and Coir Fiber on Pollution Remediation, Plant Productivity, and Nutrient Leaching, Int. J. Environ. Res. Public. Health 16 (7) (2019) 1-16, doi: https://doi.org/10.3390/ijerph16071261.

66. R. A. Chirakkara, K. R. Reddy, Biomass and chemical amendments for enhanced phytoremediation of mixed contaminated soils, Ecol. Eng. 85 (2015) 265-274, doi: https://doi. org/10.1016/j.ecoleng.2015.09.029.

67. S. Park, K. S. Kim, J. T. Kim, D. Kang, K. Sung, Effects of humic acid on phytodegradation of petroleum hydrocarbons in soil simultaneously contaminated with heavy metals, J. Environ. Sci. 23 (12) (2011) 2034-2041, doi: https://doi.org/10.1016/ S1001-0742(10)60670-5.

68. I. Merino, V. M. Campos, L. Pacios, L. Gomez, Review. Phytoremediation of Organic Pollutants, Span. J. Agric. Res., 6 (S1) (2008) 38-47, doi: https://doi.org/10.5424/ sjar/200806S1-372.

69. V. Dushenkov, M. Skarzhinskaya, K. Glimelius, D. Gleba, I. Raskin, Bioengineering of a Phytoremediation Plant by Means of Somatic Hybridization, Int. J. Phytoremediation 4 (2) (2002) 117-126, doi: https://doi. org/10.1080/15226510208500077.

70. N. Rodríguez Eugenio, P. Paya Pérez, Status of Local Soil Contamination in Europe, Publications Office of the European Union, Luxembourg, 2018., doi: https://doi. org/10.2760/093804. 


\section{SUMMARY \\ Phytoremediation - Overview and Perspective}

Nevena Milčić, Zvjezdana Findrik Blažević, and Marija Vuković Domanovac

Remediation of soils contaminated with complex mixtures of organic compounds and heavy metals is one of the greatest challenges of environmental renewal. Phytoremediation is the name for a set of techniques that employ plants, their enzymes, and associated microorganisms in the root zone for isolation, transport, detoxification, and mineralization of xenobiotics in the soil, thereby reducing their concentration, mobility or toxic effects. Phytoextraction, phytostabilization, phytovolatization, phytodegradation, and rhizodegradation have a great potential for non-destructive remediation of soils as shown by numerous laboratory-scale studies. In order for phytoremediation to become a reliable technology for a wide range of applications at a larger scale, resources need to be invested in a new research with an aim to better understand the process as a whole, especially at the genetic and biochemical levels.

\section{Keywords}

Phytomediation, soil contamination, heavy metals, organic pollutants, xenobiotics

Faculty of Chemical Engineering and Technology University of Zagreb

Marulićev trg 19

10000 Zagreb, Croatia
Review

Received July 26, 2019 Accepted August 26, 2019 